\title{
The Quality Management of Cultural Affairs of State Universities and Colleges in Eastern Visayas
}

\author{
Ryan Teofel Padecio Arpon ${ }^{\mathrm{a} *}$, Noel P. Tancinco ${ }^{\mathrm{b}}$ \\ College of Education, Naval State University, P.I. Garcia St. Naval, Biliran Province
}

\begin{abstract}
This study aimed to determine the quality management of cultural affairs provided by and State Universities and Colleges (SUC's) in Eastern Visayas in which leading to developing a strategic quality management of operation.To attain the objectives of this study, the descriptive survey method was utilized in obtaining data and information.It has been found out that the dance troupe was the strongest among all mentioned performing groups in the Cultural Affairs Development Office and the weakest groups were Brass Band, Theater Club and Cheer Leading Varsity.Meanwhile, the office personnel/staff have a thorough understanding on their responsibility which seemingly implies that the office has seen to it that there are no overlapping of duties and responsibilities to have a better system inside the office. With regards to strategy implementation on the complaints from students, and faculty and non-teaching staff were periodically analyzed to identify quality problems obtained the lowest mean. Moreover, the office head rarely consults with the students, faculty and staff about the quality management practices of the office towards its development and found out that only in rare situations that the office is involved based on the comments of the students, faculty and staff in the planning of the organization and so with the benchmarking on its effectiveness among other academic institutions in the locality and in the region as well.The support from the administration and involvement of the officials were a serious problem met in the delivery of quality cultural services. Lack of funds was another hardship and also inadequate manpower to help in the quality operation services in the office.
\end{abstract}

Key Terms: Cultural Affairs; Quality Management; State Universities and Colleges.corresponding author

\section{INTRODUCTION}

The Cultural Services Office which caters particularly cultural-related activities and concerns is one of the agencies which provide support to the University in sustaining quality and satisfactory academic-related services to students, clienteles and stakeholders. Hence, this Office envisions in promoting total quality management operations and better services to maintain its role as a strong pillar to the entire University.Drucker (2001) cited that one of the pillars of total quality and total customer satisfaction is based on the cornerstone of strategy planning and the foundation of strategy management. Total customer satisfaction incorporates both inventing and exceeding customer expectations overtime. The evolution of a quality philosophy begins with listening to the voice of the customer. Quality management practices threads this voice throughout the product and service development process. The pillar of customer satisfaction is the outcome of the subordination of sound design developed in the cornerstone of strategy planning with effective implementation delivered in the foundation of strategy management.In the same vein, the International Organization for Standardization (ISO) states that quality management system requires documentation that includes quality manual, procedures, as well as work instructions. All documentations must be controlled according to a document control procedure.

Tasked with such vision and optimism, the cultural services of the SUC's in Eastern Visayas has to be assessed with the end in view of developing and improving strategic quality management of operations in order to realize the dream of promoting total quality management of operations and better services to the entire community since global competition is now at stake and that every institution must aims to provide relevant development programs to the students and stakeholders.For years in operations, the SUC's has provided cultural affairs services to students, clienteles and stakeholders along with other functions. The researcher, being a part of Cultural Affairs Development Office (CADO) finds it highly important to assess and finds out whether the cultural affairs development has provided better services that both satisfies the internal and external measures of quality contributory to total strategic quality management of operations to the University in general.

Seemingly, the expectations of the Cultural Affairs Development Office of the University have not been attained as shown in the 2008 report of the AACCUP (Accrediting Agency of Chartered Colleges and Universities of the Philippines). The report underscores that the CADO, as part of the pillars in providing services to the students and clientele stakeholders was performing the lowest as compared with the other performance of the instruction and production programs implemented by the universities. 
This report signals the need for strategic quality management of operations of the cultural affairs development to contextualize the performance gap that existed between what is to be done and has been done.

\section{OBJECTIVES OF THE STUDY}

This study primarily aimed to determine the quality management of cultural affairs provided by and State Universities and Colleges (SUC's) in Eastern Visayas in which the end in views of developing a strategic quality management of operation.Specifically, this study seeks to attain the following questions:

1. Determine the profile of the faculty and support staff of the Cultural Affairs Development Office (CADO) in terms of the following:age;sex;civil status; educational qualifications; units earned in cultural affairs development;in-service trainings attended in cultural affairs development; andWork experience related to cultural affairs services.

2. Find out the extent of implementation of the various activities undertaken by the Cultural Affairs Development Office.

3. Ascertain strategic directions manifested by the SUC's Cultural Affairs Development Office (CADO) in terms of implementing the following: vision;mission;goals; andstrategies.

4. Determine the quality operations, management and delivery servicesmanifested by the Cultural Affairs Development Office (CADO) as perceived by the faculty, support staff, students and community along the following areas: Stakeholders satisfaction;Schools adherence to continuous improvement processes; Adherence to ethical work culture with the following parameters, and:Find out the problems met by faculty in delivering quality cultural services towards the students and community.

\section{FRAMEWORK OF THE STUDY}

The conceptual framework of the study is anchored on the philosophy that through the strategic quality management of operations for the cultural affairs development office (CADO), the university, clienteles, students and community where the university operates would find satisfactions on the quality of cultural service provided to them. The structure of this investigation has four divisions leading to its output, namely: (1) profile of the faculty and supports staff; (2) extent to which the strategic directions Implemented; (3) extent to which the quality operations, management and delivery services manifested and (4) problems met by the faculty in delivering quality cultural services heading to the quality management of cultural affairs of state universities and colleges in Eastern Visayas. Figure 1 shows the conceptual framework of the study.

\section{SCOPE AND DELIMITATION OF THE STUDY}

The respondents of the study were the students, faculty members, non-teaching personnel and clients of Cultural Affairs and Development Office of all the State Universities and Colleges in Eastern Visayas during the school year 2013-2014.

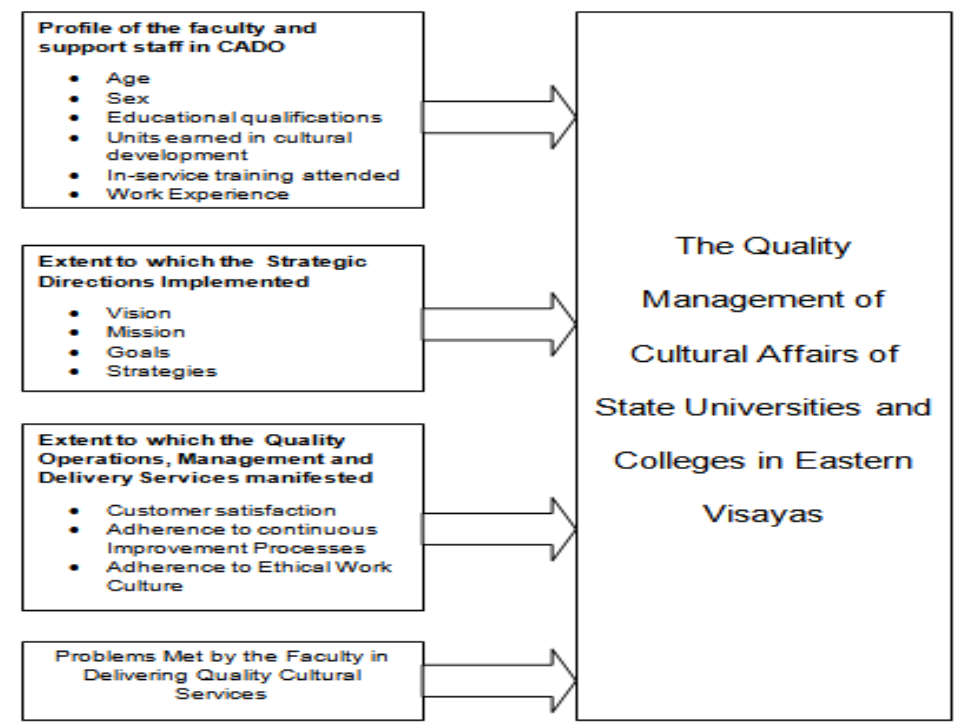

Figure 1. The Conceptual Framework of the Study

\section{METHODOLOGY}


This study utilized the descriptive-survey method. A researcher-made survey questionnaire was adopted as the main instrument for data collection. An interview was also conducted to verify the responses and answers to the questions posed by the respondents. This research was conducted among the selected state universities and colleges of Eastern Visayas, namely; Samar State University, Visayas State University, Palompon Institute of Technology, Northwest Samar State University, Southern Leyte State University, and Naval State University.The research respondents of this study were the total population of the faculty, supports staff of the Cultural Affairs Development Office and selected students from the various departments (representing the community) of the state universities and colleges of Eastern Visayas.The accomplished instrument was collected and the responses were tallied, interpreted and analyzed. The frequency, percentage, and weighted mean were used in the analysis and treatment of the data.

\section{RESULTS AND DISCUSSION}

The results were presented based on the objectives of the study. The analysis and interpretation of the faculty members and support staff's profile in terms of age, sex, age, civil status and highest degree obtained are reflected in Table 1.

Table 1. Profile of Faculty and Support Staff

\begin{tabular}{|l|l|l|}
\hline Indicators & f & \% \\
\hline Age & & \\
$20-25$ & 12 & 32.43 \\
$26-30$ & 5 & 13.51 \\
$31-35$ & 7 & 18.91 \\
$36-40$ & 3 & 8.1 \\
$41-45$ & 5 & 13.51 \\
$46-50$ & 3 & 8.1 \\
51 and above & 2 & 5.40 \\
\hline Total & $\mathbf{3 7}$ & $\mathbf{1 0 0}$ \\
\hline Sex & & \\
Male & 21 & 56.75 \\
Female & 16 & 43.24 \\
\hline Total & $\mathbf{3 7}$ & $\mathbf{1 0 0}$ \\
\hline Civil Status & & \\
Single & 18 & 48.64 \\
Married & 19 & 51.35 \\
Widow/Widower & 0 & 0 \\
\hline Total & $\mathbf{3 7}$ & $\mathbf{1 0 0}$ \\
\hline Highest degree Obtained & 0 & 0 \\
BEED & 8 & 21.62 \\
BSED & 14 & 37.83 \\
BS with Masteral Unit & 6 & 16.21 \\
Masters Degree & 3 & 8.10 \\
Masters Degree with Doctoral Unit & 1 & 2.70 \\
Doctoral Degree & 5 & 13.51 \\
Others & 37 & 100 \\
\hline Total & $\mathbf{3 7}$ & $\mathbf{1 0 0}$ \\
\hline
\end{tabular}

\begin{tabular}{|l|l|l|}
\hline Units Earned in Cultural Affairs & & \\
Development & & \\
$1-9$ & 33 & 89.19 \\
$10-18$ & 3 & 8.10 \\
$19-27$ & 0 & 0 \\
28 and above & 1 & 2.70 \\
\hline Total & $\mathbf{3 7}$ & $\mathbf{1 0 0}$ \\
\hline In Service Training Attended & & \\
Not indicated & & \\
\hline
\end{tabular}




\begin{tabular}{|l|l|l|}
\hline Work Experience Related to Cultural & & \\
Affairs Services & & \\
$1-5$ years & $\mathbf{3 2}$ & 86.49 \\
$6-10$ years & $\mathbf{0}$ & 0 \\
$11-15$ years & 4 & 10.81 \\
16 years and above & 1 & 2.70 \\
\hline Total & $\mathbf{3 7}$ & $\mathbf{1 0 0}$ \\
\hline
\end{tabular}

It could be seen from the table that out of 37 faculty and staff, 12 or 32.43 percent belonged to $20-25$ age group, and 2 or 5.40 percent belonged to 51 and above. This implies that majority of the faculty and supports staff are new in the service.Sex is categorized as male and female. As shown in the succeeding table, 21 or 56.75 percent were observed under the male category while 16 or 43.24 percent were female. This implies that in terms of faculty and staffs in the Cultural Affairs Office in the Eastern Visayas Region of state colleges and universities majority were male. For Civil status, this is categorized as single, married, widow/widower. As reflected in the table, 18 or 48.64 percent of the faculty and staff were single, 19 or 51.35 percent were married and 0 percent were widow or widower. This indicates that majority of the faculty and staffs are married. While for Highest educational degree attained, as reflected in the foregoing table, 14 or 37.83 percent were bachelor degree holder with masteral units, 8 or 21.62 percent were bachelor degree holder, 6 or 16.21 were masteral degree holders, 3 or 8.10 were master's degree holder with doctoral units, 1 or 2.70 percent was doctoral degree holder, 5 or 13.51 percent came from other courses who has inclination and passion in the cultural affairs development and 0 percent in the elementary education program. This manifests that majority of the faculty and supports staff in the Cultural Affairs and Development Office in Eastern Visayas are graduates of bachelor's degree with masteral units which corresponds to the age group of 20-25. Further, this implies that there is a need of upgrading the faculty and staff in their professional career for quality cultural services. Units earned in the Cultural Affairs Development Office as reflected in the succeeding table, 33 or 89.19 percent had 1-9 units among the faculty and staff, 3 or 8.10 percent had 10-18 units, 1 or 2.70 percent had 28 units and above and none from units earned of 19-27. As shown in the results, it is evident that majority of the faculty and support staff has only earned few units in the cultural affairs development courses. In-service training attended, the respondents did not indicate the seminars and trainings they attended. Thus, the data imply that more training should be done and be provided. Moreover, more participants should be sent for various in-service trainings to keep abreast with the trends in cultural development. Work experience related to cultural affairs. As reflected in table 2, 32 or 86.49 percent of the faculty and support staffs had a 1-5 year work experience related to cultural affairs services, 4 or 10.81 percent had 6-10 years, 1 or 2.70 percent had 16 years and above work experience and none from 19-27 years.

Extent of Implementation of the Various Activities Undertaken/Organized by the Cultural Affairs

Development Office. This is presented in Table 2. Looking at the table below, it could be seen that among the 37 faculty and staff respondents, the Dance Troupe obtained the highest weighted mean of 4.43 and interpreted as "very satisfactorilyundertaken/organized" while the Cheer Leading Varsity got the lowest mean of 3.19 interpreted as "satisfactorily undertaken/organized", Marching Band obtained a mean of 4.11 interpreted as "very satisfactorily undertaken/organized", the Theater Club got a mean of 3.62 interpreted as "satisfactorily undertaken/organized". Interpreted as "very satisfactorily undertaken/organized" the Glee Club obtained a mean of 4.05, on Music Instrument Ensemble it obtained a mean of 3.84 interpreted as "very satisfactorily undertaken/organized", the Dance Sports got the weighted mean of 4.08 interpreted as "very satisfactorily undertaken/organized" and the Hiphop Group obtained a mean of 3.65 interpreted as "satisfactorily undertaken/organized".

Table 2. Extent of Implementation of the various Activities Undertaken/Organized by the Cultural Affairs Development Office

\begin{tabular}{|l|l|l|l|l|}
\hline \multirow{2}{*}{ Indicators } & \multicolumn{2}{|l|}{ Faculty and Support Staff } & \multicolumn{2}{l|}{ Students } \\
\cline { 2 - 5 } & $\begin{array}{c}\text { W } \\
\text { M }\end{array}$ & Description & $\begin{array}{l}\text { W } \\
\text { M }\end{array}$ & Description \\
\hline Brass Band & 3.65 & $\begin{array}{l}\text { Satisfactorily } \\
\text { Undertaken/Organized }\end{array}$ & 3.00 & $\begin{array}{l}\text { Satisfactorily } \\
\text { Undertaken/Organized }\end{array}$ \\
\hline Marching Band & 4.11 & $\begin{array}{l}\text { Very Satisfactorily } \\
\text { Undertaken/Organized }\end{array}$ & 3.43 & $\begin{array}{l}\text { Satisfactorily } \\
\text { Undertaken/Organized }\end{array}$ \\
\hline
\end{tabular}


The quality management of Cultural affairs

\begin{tabular}{|l|l|l|l|l|}
\hline Theater Club & 3.62 & $\begin{array}{l}\text { Satisfactorily } \\
\text { Undertaken/Organized }\end{array}$ & 3.12 & $\begin{array}{l}\text { Satisfactorily } \\
\text { Undertaken/Organized }\end{array}$ \\
\hline Glee Club & 4.05 & $\begin{array}{l}\text { Very Satisfactorily } \\
\text { Undertaken/Organized }\end{array}$ & 3.51 & $\begin{array}{l}\text { Satisfactorily } \\
\text { Undertaken/Organized }\end{array}$ \\
\hline $\begin{array}{l}\text { Music Instrument } \\
\text { Ensemble }\end{array}$ & 3.84 & $\begin{array}{l}\text { Very Satisfactorily } \\
\text { Undertaken/Organized }\end{array}$ & 3.75 & $\begin{array}{l}\text { Very Satisfactorily } \\
\text { Undertaken/Organized }\end{array}$ \\
\hline Dance Troupe & 4.43 & $\begin{array}{l}\text { Very Satisfactorily } \\
\text { Undertaken/Organized }\end{array}$ & 4.33 & $\begin{array}{l}\text { Very Satisfactorily } \\
\text { Undertaken/Organized }\end{array}$ \\
\hline $\begin{array}{l}\text { Cheer Leading } \\
\text { Varsity }\end{array}$ & 3.19 & $\begin{array}{l}\text { Satisfactorily } \\
\text { Undertaken/Organized }\end{array}$ & 3.14 & $\begin{array}{l}\text { Satisfactorily } \\
\text { Undertaken/Organized }\end{array}$ \\
\hline Dance Sports & 4.08 & $\begin{array}{l}\text { Very Satisfactorily } \\
\text { Undertaken/Organized }\end{array}$ & 4.04 & $\begin{array}{l}\text { Very Satisfactorily } \\
\text { Undertaken/Organized }\end{array}$ \\
\hline Hiphop Group & 3.65 & $\begin{array}{l}\text { Satisfactorily } \\
\text { Undertaken/Organized }\end{array}$ & 3.94 & $\begin{array}{l}\text { Very } \\
\text { Undertaken/Organized }\end{array}$ \\
\hline AWM & $\mathbf{3 . 8 5}$ & $\begin{array}{l}\text { Very Satisfactorily } \\
\text { Undertaken/Organized }\end{array}$ & $\mathbf{3 . 5 8}$ & $\begin{array}{l}\text { Satisfactorily } \\
\text { Undertaken/Organized }\end{array}$ \\
\hline
\end{tabular}

On the other hand, the perceptions of the 230 student respondents on the extent of implementation of the various activities undertaken/organized by the cultural affairs development office, the Dance Troupe obtained the highest weighted mean of 4.33 percent interpreted as "very satisfactorily undertaken/organized" while the Brass Band got the least mean of 3.00 interpreted as "satisfactorily undertaken/organized". The Marching Band obtained 3.43 and interpreted as "satisfactorily undertaken/organized", Theater Club got 3.12 and interpreted as "satisfactorily undertaken/organized", The Glee Club obtained 3.51 and interpreted as "satisfactorily undertaken/organized". For Music Instrument Ensemble, it obtained 3.75 and interpreted as "very satisfactorily undertaken/organized", Cheer Leading Varsity got 3.14 and interpreted as "satisfactorily undertaken/organized", Dance Sports obtained 4.04 and interpreted as "very satisfactorily undertaken/organized" and the Hiphop Group obtained 3.94 and interpreted as "very satisfactorily undertaken/organized".

From these findings and data, it could be implied that the Cultural Affairs Development Office needs to strengthen its functions and responsibilities in developing the cultural activities of the University specifically the Brass Band, Theater Club and Cheer Leading Varsity because these three areas obtained less weighted mean as to both the faculty and support staff and student respondents.

\section{Strategic Directions Manifested in the Vision of the School}

The Table 3 below shows the strategic directions manifested on the vision of the school, thus it will present how the vision relates to the cultural affairs development.

Table 3. Strategic Directions Manifested in the Vision of the School

\begin{tabular}{|l|l|l|l|l|}
\hline \multirow{2}{*}{ Indicator } & \multicolumn{2}{|l|}{$\begin{array}{l}\text { Faculty and Support } \\
\text { Staff }\end{array}$} & \multicolumn{2}{l|}{ Student } \\
\cline { 2 - 5 } & $\begin{array}{l}\text { W } \\
\text { M }\end{array}$ & Description & $\begin{array}{l}\text { W } \\
\text { M }\end{array}$ & Description \\
\hline $\begin{array}{l}\text { The Vision clearly states } \\
\text { what the Institution hopes } \\
\text { to become in the future. }\end{array}$ & $\begin{array}{l}4.0 \\
8\end{array}$ & $\begin{array}{l}\text { Very } \\
\text { Satisfactorily } \\
\text { Manifested }\end{array}$ & 4.44 & $\begin{array}{l}\text { Very } \\
\text { Satisfactorily } \\
\text { Manifested }\end{array}$ \\
\hline $\begin{array}{l}\text { The vision creates a sense } \\
\text { of belongingness, } \\
\text { alignment and } \\
\text { togetherness. }\end{array}$ & 4.3 & $\begin{array}{l}\text { Very } \\
\text { Satisfactorily } \\
\text { Manifested }\end{array}$ & 4.2 & $\begin{array}{l}\text { Sery } \\
\text { Matisfactorily }\end{array}$ \\
\hline $\begin{array}{l}\text { It orients \& provides a } \\
\text { sense of purpose and } \\
\text { meaning. }\end{array}$ & 4.4 & $\begin{array}{l}\text { Very } \\
\text { Satisfactorily } \\
\text { Manifested }\end{array}$ & 4.15 & $\begin{array}{l}\text { Satisfactorily } \\
\text { Manifested }\end{array}$ \\
\hline $\begin{array}{l}\text { It captures people's } \\
\text { hearts, minds \& spirit }\end{array}$ & $\begin{array}{l}4.2 \\
3\end{array}$ & $\begin{array}{l}\text { Very } \\
\text { Satisfactorily } \\
\text { Manifested }\end{array}$ & 4.08 & $\begin{array}{l}\text { Very } \\
\text { Satisfactorily } \\
\text { Manifested }\end{array}$ \\
\hline
\end{tabular}




\begin{tabular}{|c|c|c|c|c|}
\hline $\begin{array}{l}\text { It gives a sense of } \\
\text { security, stability \& clear } \\
\text { destiny of what the } \\
\text { institution is becoming. }\end{array}$ & $\begin{array}{l}4.5 \\
7\end{array}$ & $\begin{array}{l}\text { Very } \\
\text { Satisfactorily } \\
\text { Manifested }\end{array}$ & 4.18 & $\begin{array}{l}\text { Very } \\
\text { Satisfactorily } \\
\text { Manifested }\end{array}$ \\
\hline AWM & $\begin{array}{l}4.3 \\
2\end{array}$ & $\begin{array}{l}\text { Very } \\
\text { Satisfactorily } \\
\text { Manifested }\end{array}$ & 4.21 & $\begin{array}{l}\text { Very } \\
\text { Satisfactorily } \\
\text { Manifested }\end{array}$ \\
\hline
\end{tabular}

Based on the foregoing table, all indicators that receive the mean from 4.08 to 4.57 are interpreted as "very satisfactorily manifested" from the faculty and supports staff respondents. Similarly, the student respondents' view on the strategic direction manifested on vision of the school has reached from 4.08 to 4.44 and interpreted as "very satisfactorily manifested".It had been found out that both results were high, and this just manifest that the strategic directions manifested on the vision of the school with regards to Cultural Affairs Development has been crafted well to cater what the university is expected to become in the future.

\section{Strategic Directions Manifested in the Mission of the School}

This portion presents the strategic direction manifested on the mission of the school, to show how the mission of the school provides a clear path towards the organization's success. Table 4 reveals that majority of 37 faculty and support staff respondents on the strategic direction manifested on mission of the school rated the indicators from 3.78 to 4.48 mean and interpreted as "very satisfactorily manifested".

Table 4. Strategic Directions Manifested in the Mission of the School

\begin{tabular}{|l|l|l|l|l|}
\hline \multirow{2}{*}{ Indicators } & \multicolumn{2}{|l|}{ Faculty and Support Staff } & \multicolumn{2}{l|}{ Student } \\
\cline { 2 - 6 } & WM & Description & WM & Description \\
\hline $\begin{array}{l}\text { The mission clearly reflects the } \\
\text { institution's legal and educational } \\
\text { mandate }\end{array}$ & 4.48 & $\begin{array}{l}\text { Very Satisfactorily } \\
\text { Manifested }\end{array}$ & 4.27 & $\begin{array}{l}\text { Very } \\
\text { Satisfactorily } \\
\text { Manifested }\end{array}$ \\
\hline $\begin{array}{l}\text { It reflects the organization's } \\
\text { beliefs }\end{array}$ & 4.35 & $\begin{array}{l}\text { Very Satisfactorily } \\
\text { Manifested }\end{array}$ & 3.96 & $\begin{array}{l}\text { Very } \\
\text { Satisfactorily } \\
\text { Manifested }\end{array}$ \\
\hline $\begin{array}{l}\text { It embodies the institution's values } \\
\text { \& belief system }\end{array}$ & 3.78 & $\begin{array}{l}\text { Very Satisfactorily } \\
\text { Manifested }\end{array}$ & 4.03 & $\begin{array}{l}\text { Very } \\
\text { Satisfactorily } \\
\text { Manifested }\end{array}$ \\
\hline $\begin{array}{l}\text { It defines the institution's overall } \\
\text { purpose or reason of existence }\end{array}$ & 4.32 & $\begin{array}{l}\text { Very Satisfactorily } \\
\text { Manifested }\end{array}$ & 4.09 & $\begin{array}{l}\text { Very } \\
\text { Satisfactorily } \\
\text { Manifested }\end{array}$ \\
\hline \multicolumn{1}{|c|}{ AWM } & $\mathbf{4 . 2 3}$ & $\begin{array}{l}\text { Very Satisfactorily } \\
\text { Manifested }\end{array}$ & $\mathbf{4 . 0 9}$ & $\begin{array}{l}\text { Very } \\
\text { Satisfactorily } \\
\text { Manifested }\end{array}$ \\
\hline
\end{tabular}

In the same way, the 230 student respondents, perceived it with a mean from 3.96 to 4.27 and interpreted as "very satisfactorily manifested". The data gathered only imply that most faculty, support staff, and student respondents perceived that the mission of the school visibly recommend the institution's legal and educational mandates and that it reflects the beliefs of the organization.

\section{Strategic Directions Manifested in the Goals of the School}

Table 5 shows the strategic direction manifested in the goals of the school. It can be seen here how the goals of the school will affect and strengthen the organization. As shown in the abovementioned table, the faculty and supports staff respondents specify that the strategic directions manifested on goals of the school is interpreted as "very satisfactorily manifested" as it reflects in the weighted mean of 3.93 to 4.22 . The student respondents seemingly have the same perception as shown in the weighted mean of 3.81 to 4.11 and interpreted as "very satisfactorily manifested". This implies that the institution has a clear portrait of its goals as it relates to the cultural affairs development.

Table 5. Strategic Directions Manifested in the Goals of the School

\begin{tabular}{|l|l|l|l|l|}
\hline \multirow{3}{*}{ Indicator } & \multicolumn{2}{|l|}{$\begin{array}{l}\text { Faculty and Support } \\
\text { Staff }\end{array}$} & Student \\
\cline { 2 - 5 } & WM & Description & WM & Description \\
\hline
\end{tabular}


The quality management of Cultural affairs

\begin{tabular}{|l|l|l|l|l|}
\hline $\begin{array}{l}\text { Strengthening of Cultural } \\
\text { Affair Development Service }\end{array}$ & 4.11 & $\begin{array}{l}\text { Very } \\
\text { Satisfactorily } \\
\text { Manifested }\end{array}$ & 4.22 & $\begin{array}{l}\text { Very } \\
\text { Satisfactorily } \\
\text { Manifested }\end{array}$ \\
\hline Resource Development & 4.08 & $\begin{array}{l}\text { Very } \\
\text { Satisfactorily } \\
\text { Manifested }\end{array}$ & 4.02 & $\begin{array}{l}\text { Very } \\
\text { Satisfactorily } \\
\text { Manifested }\end{array}$ \\
\hline $\begin{array}{l}\text { Institutionalization or } \\
\text { Reward System }\end{array}$ & 3.95 & $\begin{array}{l}\text { Very } \\
\text { Satisfactorily } \\
\text { Manifested }\end{array}$ & 3.93 & $\begin{array}{l}\text { Very } \\
\text { Satisfactorily } \\
\text { Manifested }\end{array}$ \\
\hline $\begin{array}{l}\text { Partnership / Linkaging } \\
\text { Strategies }\end{array}$ & 3.81 & $\begin{array}{l}\text { Very } \\
\text { Satisfactorily } \\
\text { Manifested }\end{array}$ & 3.96 & $\begin{array}{l}\text { Very } \\
\text { Satisfactorily } \\
\text { Manifested }\end{array}$ \\
\hline AWM & $\mathbf{3 . 9 8}$ & $\begin{array}{l}\text { Very } \\
\text { Satisfactorily } \\
\text { Manifested }\end{array}$ & $\mathbf{4 . 0 3}$ & $\begin{array}{l}\text { Very } \\
\text { Satisfactorily } \\
\text { Manifested }\end{array}$ \\
\hline
\end{tabular}

\section{Strategic Directions Manifested on Strategies of the School}

In this table presents the strategic direction manifested on strategies of the school; it can be seen here the approaches on how the school affects on the promotion of the cultural affairs.

Table 6. Strategic Directions Manifested on Strategies of the School

\begin{tabular}{|c|c|c|c|c|}
\hline \multirow{2}{*}{ Indicator } & \multicolumn{2}{|c|}{$\begin{array}{l}\text { Faculty and } \text { Support } \\
\text { Staff }\end{array}$} & \multicolumn{2}{|c|}{ Student } \\
\hline & $\begin{array}{l}\mathbf{W} \\
\mathbf{M}\end{array}$ & Description & WM & Description \\
\hline $\begin{array}{l}\text { Review/Update Cultural } \\
\text { Affairs } \\
\text { Policies/Guidelines }\end{array}$ & 3.94 & $\begin{array}{l}\text { Very Satisfactorily } \\
\text { Manifested }\end{array}$ & 4.14 & $\begin{array}{l}\text { Very Satisfactorily } \\
\text { Manifested }\end{array}$ \\
\hline $\begin{array}{l}\text { Initiate activities that will } \\
\text { promote and enhance } \\
\text { culture in the university } \\
\text { and in the community }\end{array}$ & 3.97 & $\begin{array}{l}\text { Very Satisfactorily } \\
\text { Manifested }\end{array}$ & 4.14 & $\begin{array}{l}\text { Very Satisfactorily } \\
\text { Manifested }\end{array}$ \\
\hline $\begin{array}{l}\text { Perform not only in the } \\
\text { university but also in } \\
\text { region and national } \\
\text { events }\end{array}$ & 4.02 & $\begin{array}{l}\text { Very Satisfactorily } \\
\text { Manifested }\end{array}$ & 4.13 & $\begin{array}{l}\text { Very Satisfactorily } \\
\text { Manifested }\end{array}$ \\
\hline $\begin{array}{l}\text { Perform not only in the } \\
\text { university but also in } \\
\text { region and national area }\end{array}$ & 3.81 & $\begin{array}{l}\text { Very Satisfactorily } \\
\text { Manifested }\end{array}$ & 4.03 & $\begin{array}{l}\text { Very Satisfactorily } \\
\text { Manifested }\end{array}$ \\
\hline $\begin{array}{l}\text { Encourage every student } \\
\text { to participate in every } \\
\text { cultural activities }\end{array}$ & 4.0 & $\begin{array}{l}\text { Very Satisfactorily } \\
\text { Manifested }\end{array}$ & 4.24 & $\begin{array}{l}\text { Very Satisfactorily } \\
\text { Manifested }\end{array}$ \\
\hline AWM & 3.95 & $\begin{array}{l}\text { Very Satisfactorily } \\
\text { Manifested }\end{array}$ & 4.14 & $\begin{array}{l}\text { Very Satisfactorily } \\
\text { Manifested }\end{array}$ \\
\hline
\end{tabular}

It could be gleaned from the aforesaid table on strategic direction manifested on strategies of the school that majority of the faculty and support staff respondents noticed that strategies of the school with regards to the development of the cultural affairs is relatively high as cited by the weighted mean from 3.81 to 4.02 and interpreted as "very satisfactorily manifested".As for the student respondents, it could be similarly observed that their findings on the strategic direction manifested on strategies of the school is equally high as shown in the weighted mean from 4.03 to 4.24 and interpreted as "very satisfactorily manifested" Looking back at the table, although most of the results were revealed as "very satisfactorily manifested", the indicator number 4 got the least mean for both the faculty and support staff and the student respondents which apparently implies that most universities in the Eastern Visayas have to give more focus on maneuvering in this area since performing in the national arena for the cultural groups/organization means a big amount of money. Furthermore, practices and 
rehearsals would evidently affect the academic performances of the student performers and so even with the faculty and staff as to their instructions to their other classes.

\section{Quality Operations and Management and Delivery Services on Strategy Formulation}

It can be seen in the succeeding table the quality operations and management and delivery services on strategy formulation, how the respondents distinguish and recognize the formulated strategies by the school in terms of stakeholder 's satisfaction.

Table 7. Quality Operations and Management and DeliveryServices on Strategy Formulation

\begin{tabular}{|c|c|c|c|c|}
\hline \multirow{2}{*}{ Indicator } & \multicolumn{2}{|c|}{$\begin{array}{ll}\text { Faculty } & \text { and } \\
\text { Support Staff } & \\
\end{array}$} & \multicolumn{2}{|c|}{ Student } \\
\hline & $\begin{array}{l}\mathbf{W} \\
\mathbf{M}\end{array}$ & Description & $\begin{array}{l}\mathbf{W} \\
\mathbf{M}\end{array}$ & Description \\
\hline $\begin{array}{l}\text { The Cultural Affairs Development Office } \\
\text { has explicitly articulated its university's } \\
\text { mission of desired future. }\end{array}$ & 4.16 & Often & 4.02 & Often \\
\hline $\begin{array}{l}\text { The Cultural Affairs Development Office } \\
\text { has made a clear mission statement with } \\
\text { prioritized and shared values }\end{array}$ & 3.91 & Often & 4.06 & Occasionally \\
\hline $\begin{array}{l}\text { The Cultural Affairs Development Office } \\
\text { explicitly endorses quality strategic } \\
\text { objectives }\end{array}$ & 3.24 & Occasionally & 3.86 & Often \\
\hline $\begin{array}{l}\text { The Office aligns its strategies to } \\
\text { coherently provide the highest quality of } \\
\text { education to the community }\end{array}$ & 4.14 & Often & 4.06 & Occasionally \\
\hline $\begin{array}{l}\text { The Office regularly solicits students, } \\
\text { faculty and employees' inputs on the } \\
\text { feasibility of the commitment to } \\
\text { formulated strategies }\end{array}$ & 3.97 & Often & 3.70 & Often \\
\hline $\begin{array}{l}\text { The Office accords strategic priority to } \\
\text { satisfying customers/clients whether } \\
\text { internal or external }\end{array}$ & 3.73 & Often & 3.7 & Often \\
\hline $\begin{array}{l}\text { The Office head demonstrates by word } \\
\text { and deed thatcustomer satisfaction is a } \\
\text { strategic priority }\end{array}$ & 4.0 & Often & 3.83 & Often \\
\hline $\begin{array}{l}\text { The Office benchmarks its services to } \\
\text { provide the best value for its internal and } \\
\text { external client }\end{array}$ & 3.97 & Often & 3.77 & Often \\
\hline AWM & 3.89 & Often & 3.88 & Often \\
\hline
\end{tabular}

Table 7 shows the extent of the quality operations and management and delivery services on strategy formulation. As to the perception of the faculty and support staff, the indicator 1 obtained the highest mean of 4.16 and interpreted as "Often", which means the Cultural Affairs Development Office has clearly delivered its schools mission of desired future. On the otherhand, indicator 3 got the least mean which siginifies that the extent of delivery of the quality strategic objectives was a bit low.As for the students' views, indicators 2 and 4 obtained the highest mean of 4.06 which shows that the Cultural Affairs Development Office has made a clear mission statement with prioritized and shared values and that the office aligns its strategies to coherently provide the highest quality of education to the community interpreted both as "Always ". On the contrary, though interpreted as "Often", the student respondents perceived indicators 5 and 6 obtained a lower mean of 3.7 than the rest.As a whole, the result implies that strategy formulation of the quality operations and manangement and delivery services of the Cultural Affairs Development Office is on its way to excellence. Further, universities must keep on track of the quality operation especially on the sustainability of its services.

\section{Quality Operations and Management and Delivery Services On Strategy Implementation}

Below is a presentation on the quality operation and management and delivery services on strategy implementation. Here, it could be observed that the respondents' views on how the Cultural Affairs Development Office carry out the implementations of the organization and its strategies formulated.

Table 8. Quality Operations and Management and Delivery ServicesOn Strategy Implementation 


\begin{tabular}{|l|l|l|l|l|}
\hline \multirow{2}{*}{ Indicator } & \multicolumn{2}{|l|}{$\begin{array}{l}\text { Faculty and Support } \\
\text { Staff }\end{array}$} & \multicolumn{2}{l|}{ Student } \\
\cline { 2 - 6 } & WM & Description & WM & Description \\
\hline $\begin{array}{l}\text { The Office understands and streamlines its } \\
\text { processes to effectively implement } \\
\text { strategies }\end{array}$ & 3.84 & Often & 4.35 & Often \\
\hline $\begin{array}{l}\text { The Office utilizes cross functional teams to } \\
\text { solve cross organizational problems }\end{array}$ & 3.78 & Often & 3.92 & Often \\
\hline $\begin{array}{l}\text { The Office trains its people to make use of } \\
\text { quality managementpractices }\end{array}$ & 3.70 & Often & 4.00 & Often \\
\hline $\begin{array}{l}\text { The Office ensures its students, faculty and } \\
\text { employeesto actively contribute its quality } \\
\text { management goals }\end{array}$ & 3.97 & Often & 4.10 & Often \\
\hline $\begin{array}{l}\text { The Office provides opportunities for open } \\
\text { communication linesfor students, faculty } \\
\text { and employees }\end{array}$ & 3.89 & Often & 4.04 & Often \\
\hline $\begin{array}{l}\text { The Office head regularly gives information } \\
\text { to itsmembers that help shape realistic } \\
\text { expectations }\end{array}$ & 3.73 & Often & 3.92 & Often \\
\hline $\begin{array}{l}\text { Complaints from students, faculty and non- } \\
\text { teaching Staff are periodically analyzed in } \\
\text { order to identify quality problems }\end{array}$ & 3.62 & Occasionally & 3.86 & Often \\
\hline AWM & 3.79 & Often & 4.03 & Often \\
\hline
\end{tabular}

The table above shows that among the total faculty and supports staff respondents, the weighted mean was not that high from 3.62 to 3.97. The indicator 4 as shown in Table 9 obtained the highest mean among all other indicators of 3.97 and interpreted as "Often" which means the office ensures its students, faculty and employees to actively contribute its quality management goals. On the contrary, indicator 7 obtaineda mean of 3.62 and interpreted as "Occasionally"; this refers to the strategy implementation on the complaints from students, and faculty and non-teaching staff are periodically analyzed in order to identify quality problems. This result indicates that in this area of strategy implementation of the Cultural Affairs Development Office was not given much attention. Complaints and criticisms must be valued and must not be taken for granted or ignored as it will contribute much on the improvement of the office as it will likewise help in benchmarking for planning, formulating and implementing the services of the office in the future.Looking back to the table regarding the student respondents perception on the extent of strategy implementation on the quality operation and management and delivery services, indicator 1 got the highest mean of 4.35 as interpreted as "Often", that the office understands its processes to effectively implement strategies and the lowest mean is indicator 7 with 3.86 and interpreted as "Often". As a whole, both the faculty and supports staff and the student respondents have a common contemplation on the complaints from students, and faculty and non-teaching staff are periodically analyzed in order to identify quality problems and based on the result of the gathered data; this implies that complaints and comments may they be good or not must be given a chance to be analyzed and be evaluated if it will surely help on the improvement of the quality operation management of the Cultural Affairs Development Office with regards to the identification of the quality problems on the strategy implementation.

Quality Operations and Management and Delivery Services On Strategy Evaluation and Control

The evaluation and control in the office can be seen here through the respondents opinion on how they rated the indicators given.

Table 9. Quality Operations and Management and Delivery Services On Strategy Evaluation and Control

\begin{tabular}{|l|l|l|l|l|}
\hline \multirow{2}{*}{ Indicator } & \multicolumn{2}{|l|}{$\begin{array}{l}\text { Faculty and Support } \\
\text { Staff }\end{array}$} & \multicolumn{2}{l|}{ Student } \\
\cline { 2 - 6 } & WM & Description & WM & Description \\
\hline $\begin{array}{l}\text { The Office assesses the effectiveness of } \\
\text { itsmanagement practices regularly }\end{array}$ & 3.84 & Often & 3.9 & Often \\
\hline
\end{tabular}




\begin{tabular}{|l|l|l|l|l|}
\hline $\begin{array}{l}\text { The output achieved by the } \\
\text { office(graduates, quality of teaching } \\
\text { and training) is regarded as high quality) }\end{array}$ & 3.78 & Often & 3.92 & Often \\
\hline $\begin{array}{l}\text { The outcome (effect of the output to } \\
\text { society and community) of the Office is } \\
\text { regard as beneficial }\end{array}$ & 3.97 & Often & 3.74 & Often \\
\hline $\begin{array}{l}\text { The Office conducts and administers } \\
\text { employees attitudinal exams, and student } \\
\text { surveys and disseminate their results }\end{array}$ & 3.54 & Occasionally & 3.83 & Often \\
\hline $\begin{array}{l}\text { The Office benchmarks its effectiveness } \\
\text { with that of other academic institutions in } \\
\text { the locality and other region }\end{array}$ & 3.67 & Occasionally & 3.79 & Often \\
\hline $\begin{array}{l}\text { The Office integrates students, faculty } \\
\text { andemployees, comments on the } \\
\text { organizational plan }\end{array}$ & 3.62 & Occasionally & 3.87 & Often \\
\hline $\begin{array}{l}\text { The Office head consults with its students, } \\
\text { faculty and staff about the introduction } \\
\text { and } \\
\text { development of quality management } \\
\text { practices. }\end{array}$ & 3.59 & Occasionally & 3.94 & Often \\
\hline \multicolumn{1}{|c|}{ AWM } & $\mathbf{3 . 7 2}$ & Often & $\mathbf{3 . 8 6}$ & Often \\
\hline
\end{tabular}

The table reflects the quality operations and management and delivery services on strategy evaluation and control. As reflected in the table, it shows that the faculty and supports staff's perception was divided from the indicators number 4,5,6 and 7 with the weighted mean of 3.54 to 3.59 respectively and interpreted as "occasionally" which in most cases the evaluation and control of the Cultural Affairs Development Office occasionally conducts and administers employees attitudinal exams and students surveys and on the dissemination of results. Moreover, the office head rarely consults with the students, faculty and staff about the quality management practices of the office towards its development and that it was found out that only in rare situations that the office involve the comments of the students, faculty and staff in the planning of the organization and so with the benchmarking on its effectiveness among other academic institutions in the locality and in the region as well. This result suggests that in the strategy evaluation and control of the quality operations and management and delivery services, the stakeholders should be taken into consideration for the development of the operations so as its quality management.With regards to the students' perception the indicators mean ranged from 3.83 to 3.94 and interpreted as "Often". In most cases the result shows that the office's strategy evaluation and control were not that high. This significantly implies that the revealed result on the data gathered based on the preceded table above, stakeholders must be included in the evaluation and assessment of the services rendered by the Cultural Affairs Development Office towards the effectiveness of the quality management of the office.

\section{School Adherence to Continuous Improvement Process on Planning}

In the table below presents the schools observations on the constant process on planning, thus the respondents view on how it is being done can be evidently seen here.

Table 10. School Adherence to Continuous Improvement Process on Planning

\begin{tabular}{|l|l|l|l|l|l|}
\hline \multirow{2}{*}{ Indicators } & \multicolumn{2}{|l|}{$\begin{array}{l}\text { Faculty } \\
\text { Support Staff }\end{array}$} & \multicolumn{2}{l|}{ andent } \\
\cline { 2 - 7 } & WM & Description & $\begin{array}{c}\text { W } \\
\text { M }\end{array}$ & Description \\
\hline $\begin{array}{l}\text { The Office head provides stable and } \\
\text { well-defined expectations to all } \\
\text { members of the organization }\end{array}$ & 3.89 & Often & 4.05 & Often \\
\hline $\begin{array}{l}\text { The Office provides a support system to } \\
\text { get the job done }\end{array}$ & 3.92 & Often & 3.9 & Often \\
\hline $\begin{array}{l}\text { The Office ensures that all key processes } \\
\text { work in harmony to maximize } \\
\text { organizational effectiveness and }\end{array}$ & 3.89 & Often & 3.9 & Often \\
\hline
\end{tabular}




\begin{tabular}{|c|c|c|c|c|}
\hline efficiency & & & & \\
\hline $\begin{array}{l}\text { The Office head creates and } \\
\text { discriminates information in a timely } \\
\text { manner }\end{array}$ & 3.83 & Often & 3.76 & Often \\
\hline $\begin{array}{l}\text { The Office institutes a system of } \\
\text { adapting the bestpractices in the industry }\end{array}$ & 3.97 & Often & 3.81 & Often \\
\hline $\begin{array}{l}\text { The Office eliminates bureaucracy by } \\
\text { removing necessary tasks, approvals and } \\
\text { paper works }\end{array}$ & 3.84 & Often & 3.74 & Often \\
\hline $\begin{array}{l}\text { The Office preserves the thrust of } \\
\text { excellence in sustaining the learning } \\
\text { organization }\end{array}$ & 3.89 & Often & 3.99 & Often \\
\hline AWM & 3.89 & Often & 3.88 & Often \\
\hline
\end{tabular}

In this table, the results of the data gathered in the perception of the faculty and staff with regards to the process planning ranged from 3.83 to 3.97 and interpreted as "Often". Here, it was revealed that indicator 4 had the least mean, which implies that the office head must create and discriminates information with regards to the Cultural Affairs Development Office in a very timely manner. Furthermore, the Cultural Affairs' timetable must be in line with the whole university's calendar and the office must see to it that the faculty, support staff and student must be taken into consideration in the planning of the activities. On the other hand, indicator number 5 obtained the highest mean of 3.97 and interpreted as "Often" which signifies that the office already established a system on adapting the best practices in industry; this is to keep abreast with the new trends in cultural services and development.Meanwhile, the results on the data gathered on the side of the students on the school adherence to continuous improvement in process on planning averagely ranged from 3.74 to 4.05 and interpreted as "Often" respectively. The students' perception as shown on the foregoing table gave emphasis on indicator 1 which states that the office head provides stable and well-define expectations to all members of the organization and obtained a mean of 4.05 and interpreted as "Often". On the other hand, indicator 6 obtained the least mean of 3.74 which states that the office eliminates bureaucracy by removing necessary tasks, approvals and paper works. The results imply that a plan must be crafted in order that long flow process in the office negotiations can be at least minimized.

School Adherence to Continuous Improvement Process on Student Empowerent

It can be seen in the table below on how students are being empowered as to Cultural Affairs Development Office is concerned.

Table 11. School Adherence to Continuous Improvement Process on Student Empowerent

\begin{tabular}{|l|l|l|l|l|}
\hline \multirow{2}{*}{ Indicator } & \multicolumn{2}{l|}{$\begin{array}{l}\text { Faculty and Support } \\
\text { Staff }\end{array}$} & \multicolumn{2}{l|}{ Student } \\
\cline { 2 - 6 } & WM & Description & WM & Description \\
\hline $\begin{array}{l}\text { Office personnel/staff involvement is } \\
\text { encouraged to function as a powerful } \\
\text { productivity force in the office }\end{array}$ & 3.95 & Often & 3.99 & Often \\
\hline $\begin{array}{l}\text { Bureaucratic layers are minimal in CADO } \\
\text { with little red tape required to get things } \\
\text { done }\end{array}$ & 3.78 & Often & 3.68 & Occasionally \\
\hline $\begin{array}{l}\text { The Office personnel/staff feel that they } \\
\text { becomebetter persons at work }\end{array}$ & 3.84 & Often & 3.96 & Often \\
\hline $\begin{array}{l}\text { The Office head responds to feedback and } \\
\text { queries promptly }\end{array}$ & 3.95 & Often & 3.78 & Often \\
\hline $\begin{array}{l}\text { The Office personnel/staff at all levels have } \\
\text { a thorough understanding of their } \\
\text { responsibility }\end{array}$ & 3.19 & Occasionally & 3.98 & Often \\
\hline $\begin{array}{l}\text { The Office personnel/staff have the energy, } \\
\text { skills andknow-how are rewarded } \\
\text { positively }\end{array}$ & 3.86 & Often & 3.91 & Often \\
\hline
\end{tabular}




\begin{tabular}{|l|l|l|l|l|}
\hline $\begin{array}{l}\text { Warmth and support are the characteristics } \\
\text { of the organization }\end{array}$ & 3.95 & Often & 3.94 & Often \\
\hline AWM & $\mathbf{3 . 7 9}$ & Often & $\mathbf{3 . 8 9}$ & Often \\
\hline
\end{tabular}

Table 11 shows the school adherence to continuous improvement process

on Student Empowerent. As indicated in the table, it could be rightly noted that the faculty and supports staff's view can be determined through the obtained weighted mean that ranged from 3.19 and interpreted as "Occasionally" to 3.95 and interpreted as "Occasionally". Indicators 1, 4 and 7 got the highest mean that certainly the office personnel and staff's involvement eventually help in the development of the students through the Cutural Affairs Office. Furthermore, it could also be gleaned that the office head immediately responds to feedback and queries given. And lastly, a sense of warmness can be seen as being one of the organization's characteristics. Meanwhile, the least mean is seen in indicator 5 which states that the office personnel/staff must have a thorough understanding on their responsibility which seemingly implies that the office must see to it that there will no overlapping of duties and responsibilities to have a better system inside the office as it will surely affect the student's efficacy. For the students' perception, it could be gleaned from the table that based on the results, the weighted mean obtained from 3.99 and interpreted as "Often " to 3.68 and interpreted as "occasionally". The respondents gave emphasis on the involvement of the personnel/staff with regards to functions as a powerful output in the office as it empowers the students. Least points was given to indicator number 2 as it is interpreted as "Occasionally" that states: Bureaucratic layers are minimal in the office with little red tape required to get things done. This simply implies that the office still has this system in the process that commonly misunderstood by the stakeholders because the latter thought that it will take more procedures to get things done.

\section{School Adherence to Continuous Improvement Process on Strategic and Cultural Adaptation}

Table 12 below shows the schools adherence to continuous improvement process on strategic and cultural adaptation. The perceptions of the respondents will be seen below as indicated in the table.

Table 12. School Adherence to Continuous Improvement Process On Strategic and Cultural Adaptation

\begin{tabular}{|l|l|l|l|l|}
\hline \multirow{2}{*}{ Indicator } & \multicolumn{2}{l|}{$\begin{array}{l}\text { Faculty and Support } \\
\text { Staff }\end{array}$} & \multicolumn{2}{l|}{ Student } \\
\cline { 2 - 6 } & WM & Description & WM & Description \\
\hline $\begin{array}{l}\text { A meaningful value system is promoted } \\
\text { throughout the office which inherently } \\
\text { defines appropriate behavior }\end{array}$ & 3.92 & Often & 3.54 & Occasionally \\
\hline $\begin{array}{l}\text { Personnel/staff are provided with a fairly } \\
\text { stable organization structure that makes } \\
\text { sense and works for them. }\end{array}$ & 3.97 & Often & 3.89 & Often \\
\hline $\begin{array}{l}\text { There is a principled, clear, and compelling } \\
\text { description of what the organization stands } \\
\text { for. }\end{array}$ & 3.97 & Often & 3.93 & Often \\
\hline $\begin{array}{l}\text { The Office considers quality complete- ness } \\
\text { of itseducation as its top priority }\end{array}$ & 4.05 & Often & 3.93 & Often \\
\hline $\begin{array}{l}\text { The Office considers flexibility, change, and } \\
\text { constant improvement as essential to their } \\
\text { success. }\end{array}$ & 4.16 & Often & 3.92 & Often \\
\hline $\begin{array}{l}\text { The Office encourages awareness and } \\
\text { understanding of cultural diversity by } \\
\text { developing international programs and } \\
\text { campus interactions between students/ } \\
\text { people of different culture. }\end{array}$ & 4.30 & Often & 3.93 & Often \\
\hline
\end{tabular}

On the abovementioned table, the results of the data gathered in the perception of the faculty and staff with regards to schools adherence to continuous improvement procces on strategic and cultural adaptation obtained a mean that ranged from 3.92 to 4.30 and as interpreted as "Often" respectively. It is clearly seen that emphasis is given much on indicator number 6 which greatly implies that interaction among students were seriously encouraged as it will develop awareness of understanding individual differences and cultural diversity.On the other side, the students' results on the data gathered from them shows that indicator number 3 , 
4 and 6 got the highest mean of 3.93 and interpreted as "Often" which collectively means that putting much concentration on clear and principled description of what is the organization is been up to ; quality education and awareness and understanding on cultural diversity. However, indicator 1 obtained the least mean of 3.54 and interpreted as "Occasionally", which simply shows that a serious value system is much greatly promoted and this will create a harmonious relationship inside the organization.

Adherence to Ethical Work Culture in Respect to People. Table 13 presents the ethical work culture with respect to people particularly the stakeholders.

Table 13. Adherence to Ethical Work Culture in Respect to People

\begin{tabular}{|c|c|c|c|c|}
\hline \multirow{2}{*}{ Indicator } & \multicolumn{2}{|c|}{$\begin{array}{l}\text { Faculty and Support } \\
\text { Staff }\end{array}$} & \multicolumn{2}{|c|}{ Student } \\
\hline & WM & Description & WM & Description \\
\hline $\begin{array}{l}\text { The Office treats all students, faculty and } \\
\text { clients with respect and dignity }\end{array}$ & 3.68 & Sometimes & 4.28 & Often \\
\hline $\begin{array}{l}\text { The Office is dedicated in providing training } \\
\text { to all people }\end{array}$ & 4.03 & Often & 4.06 & Often \\
\hline $\begin{array}{l}\text { There is a great deal of positive } \\
\text { reinforcement done in the office }\end{array}$ & 4.11 & Often & 3.99 & Often \\
\hline $\begin{array}{l}\text { Employees, teachers and students alike are } \\
\text { treated fairly in the office }\end{array}$ & 4.22 & Often & 3.94 & Often \\
\hline $\begin{array}{l}\text { The Office treats all its employees, teachers } \\
\text { and students like adults }\end{array}$ & 4.30 & Often & 3.97 & Often \\
\hline $\begin{array}{l}\text { The Office ensures pay equity for all people } \\
\text { in the organization }\end{array}$ & 4.16 & Often & 3.90 & Often \\
\hline AWM & 4.08 & Often & 4.02 & Often \\
\hline
\end{tabular}

As shown on table 13, the perception of the faculty and support staff on the given indicators were fairly satisfactory as its weighted mean ranged from 4.03 to 4.30 as interpreted as "Often" while for the indicator 1 that obtained only a mean of 3.68 and interpreted as "Occasionally" which simply implies that an office has a great responsibility in treating all clients fairly and equal. It is with much accord that everyone should be acknowledged and recognized whenever a client will enter into an office for whatever purpose it may be.As for the students, the result of the data gathered is quietly average as indicated in the weighted mean of 3.90 to 4.28 interpreted as "Often" which significantly implies that the office is fair in respecting people may it be a clientele, stakeholder and/or employees.

\section{Adherence to Ethical Work Culture in Principled Integrity}

This portion shows how integrity is being valued through the Cultural Affairs Development Office as it is being appraised by the given indicators below.

Table 14. Adherence to Ethical Work Culture in Principled Integrity

\begin{tabular}{|l|l|l|l|l|}
\hline \multirow{2}{*}{ Indicator } & \multicolumn{2}{l|}{$\begin{array}{l}\text { Faculty and Support } \\
\text { Staff }\end{array}$} & \multicolumn{2}{l|}{ Student } \\
\cline { 2 - 6 } & WM & Description & WM & Description \\
\hline $\begin{array}{l}\text { The Office respects the personal and } \\
\text { professional integrity of other people }\end{array}$ & 4.27 & Often & 4.14 & Often \\
\hline $\begin{array}{l}\text { The Office places high standards of moral } \\
\text { behavior in all levels of the organization }\end{array}$ & 4.22 & Often & 3.99 & Often \\
\hline $\begin{array}{l}\text { The Office develops and nurtures commitment } \\
\text { to a lifelong learning organization }\end{array}$ & 4.22 & Often & 4.01 & Often \\
\hline $\begin{array}{l}\text { The Office continually improve relationships } \\
\text { created with the multiple stakeholders }\end{array}$ & 3.97 & Often & 3.93 & Often \\
\hline $\begin{array}{l}\text { The Office integrates the principles of } \\
\text { humility, dignity and accountability to all } \\
\text { levels of the organization }\end{array}$ & 3.81 & Often & 3.93 & Often \\
\hline
\end{tabular}




\begin{tabular}{|c|l|l|l|l|}
\hline $\begin{array}{l}\text { The office conducts periodic ethics training at } \\
\text { all levels of the organization }\end{array}$ & 3.95 & Often & 3.93 & Often \\
\hline AWM & $\mathbf{4 . 0 7}$ & Often & $\mathbf{3 . 9 8}$ & Often \\
\hline
\end{tabular}

It could be found out based on the data gathered as shown in the foregoing table that the faculty and support staffs weighted mean results were obtained from 3. 81 to 4.27 and interpreted as "Often".

Similarly, the students perception is almost the same with that of the faculty and supports staff as indicated in the weighted mean that ranged from 3.93 to 4.1 and interpreted as "Often".

These both imply that with regards to respect to others, the office gives much emphasis on it and that will surely continue the good relationships among the office and the stakeholders.

\section{Adherence to Ethical Work Culture in Respect of Legitimate Authority}

The succeeding table presents the adherence to ethical work culture in respect of legitimate authority. It shows the respondents' view on the practices of the system inside the office as it pertains to hierarchy of personnel inside the organization. As shown in the result in table 15 below, it could be clearly seen that the respect on legitimate authority with regards to ethical work culture based on the on the perceptionof the faculty and support staff is collectively high as indicated in the weighted mean from 4.05 to 4.38 and interpreted as "Often" respectively. It is basically meant that the hierarchy of personnel in the office with regards to respect of positions is definitely observed. On the other side, the students results on the same data gathered were comparably high from 3.83 to 4.05 and interpreted as "Often". Both results could be collectively implied that the hierarchy of the organizational structure in the Cultural Affairs Development Office is rigidly followed and observed. The respect to each legitimate authority can still be clearly perceived.

Table 15. Adherence to Ethical Work Culture in Respect of Legitimate Authority

\begin{tabular}{|l|l|l|l|l|l|}
\hline \multirow{2}{*}{ Indicator } & \multicolumn{2}{l|}{$\begin{array}{l}\text { Faculty and Support } \\
\text { Staff }\end{array}$} & \multicolumn{2}{l|}{ Student } \\
\cline { 2 - 6 } & WM & Description & WM & Description \\
\hline $\begin{array}{l}\text { The Office is very particular with tradition } \\
\text { standard operating procedure }\end{array}$ & 4.14 & Often & 4.04 & Often \\
\hline $\begin{array}{l}\text { Directions from the above authority is } \\
\text { needed before any decision can be made. }\end{array}$ & 4.29 & Often & 3.93 & Often \\
\hline $\begin{array}{l}\text { The personnel/staff of the Office do not } \\
\text { think of themselves, but always refer to the } \\
\text { above organization for guidance. }\end{array}$ & 4.05 & Often & 3.92 & Often \\
\hline $\begin{array}{l}\text { The Office adopts conventional strategies to } \\
\text { which it expects its personnel/staff to adhere } \\
\text { to. }\end{array}$ & 4.38 & Often & 3.93 & Often \\
\hline $\begin{array}{l}\text { The Office structure is very rigid and } \\
\text { heirarchical }\end{array}$ & 4.05 & Often & 3.83 & Often \\
\hline $\begin{array}{l}\text { All decisions made pertaining to the Office } \\
\text { activities all emanate from the top }\end{array}$ & 4.16 & Often & 3.96 & Often \\
\hline $\begin{array}{l}\text { Personnel/Staff of the office respects } \\
\text { decision of the office head }\end{array}$ & 4.22 & Often & 4.05 & Often \\
\hline \multicolumn{2}{|c|}{ AWM } & $\mathbf{4 . 1 8}$ & Often & $\mathbf{3 . 9 5}$ & Often \\
\hline
\end{tabular}

Problems Met by the Faculty in Achieving CulturalServices to Clientele/Community

In the succeeding table, it is presented the problems met by the faculty in the achievement of the cultural services to the clienteles and to the community as well. It can be seen here the scenario of the other side of the coin when it comes to hardships in the organization, specifically in the Cultural Affairs Development Office.

Table 16. Problems Met by the Faculty in Achieving Cultural Services to Clientele/Community

\begin{tabular}{|ll|l|l|l|l|l|}
\hline \multirow{2}{*}{ Indicator } & \multicolumn{2}{l|}{$\begin{array}{l}\text { Faculty and Support } \\
\text { Staff }\end{array}$} & \multicolumn{3}{l|}{ Student } \\
\cline { 3 - 7 } & & WM & Description & WM & Description \\
\hline $\begin{array}{l}\text { Inadequate administration's support to } \\
\text { cultural affairs development }\end{array}$ & 3.22 & $\begin{array}{l}\text { Sometimes a } \\
\text { Problem }\end{array}$ & 3.19 & $\begin{array}{l}\text { Sometimes a } \\
\text { Problem }\end{array}$ \\
\hline
\end{tabular}


The quality management of Cultural affairs

\begin{tabular}{|c|c|c|c|c|}
\hline $\begin{array}{l}\text { Lack of funds for Cultural Affairs/ } \\
\text { Services }\end{array}$ & 3.41 & $\begin{array}{l}\text { Sometimes a } \\
\text { Problem }\end{array}$ & 3.26 & $\begin{array}{l}\text { Sometimes a } \\
\text { Problem }\end{array}$ \\
\hline Non-Involvement of other school officials & 3.27 & $\begin{array}{l}\text { Sometimes a } \\
\text { Problem }\end{array}$ & 3.07 & $\begin{array}{l}\text { Sometimes a } \\
\text { Problem }\end{array}$ \\
\hline $\begin{array}{l}\text { Inability of the School administrator to } \\
\text { supervise } \\
\text { Development }\end{array}$ & 3.35 & $\begin{array}{l}\text { Sometimes a } \\
\text { Problem }\end{array}$ & 3.00 & $\begin{array}{l}\text { Sometimes } \\
\text { Problem }\end{array}$ \\
\hline Inadequate Manpower & 3.35 & $\begin{array}{l}\text { Sometimes a } \\
\text { Problem }\end{array}$ & 3.06 & $\begin{array}{l}\text { Sometimes } \\
\text { Problem }\end{array}$ \\
\hline AWM & 3.32 & $\begin{array}{l}\text { Sometimes a } \\
\text { Problem }\end{array}$ & 3.12 & $\begin{array}{l}\text { Sometimes a } \\
\text { Problem }\end{array}$ \\
\hline
\end{tabular}

Table 16 shows the problems met by the faculty in delivering quality cultural services. It can be noted that all indicators have the same result as to perception of the faculty and support staff that is indicated in the weighted mean from 3.22 to 3.41 and interpreted as"Sometimes a Problem".In the same manner, the students' view on the problems met by the faculty in achieving quality cultural services is also minimal as indicated in the weighted mean ranged from 3.00 to 3.26 and interpreted as "Sometimes a Problem" in all indicators given. Analyzing both results, the data imply that in delivering quality cultural services the faculty as perceived by the two sets of respondents hugely needed full support from the administration in terms of funding in delivering quality cultural services to the University and to the community. With funds available, the Office could easily plan, formulate and implement programs and activities. The school officials have the power to inspire, to encourage and to guide the faculty in the office that could possibly uplift the spirit to work harder in achieving a quality operation with regards to cultural activities and of course supervision and monitoring from them in much needed. Lastly, extra hand could be of great help in the success in every activity that is being offered by the office, especially during big events in the university, because in most cases inadequate manpower certainly affect the quality of services in the Cultural Affairs Development Office

\section{CONCLUSIONS}

Based on the findings generated in the study, the following conclusions were deduced:The faculty and supports staffs working in the Cultural Affairs Development Office were mostly new in the service as to work experience in cultural affairs development and were emphasized with fewer units earned in cultural affairs development. Also, the quality of performances, functions and responsibilities of some of the cultural activities of the university specifically the Brass Band, Theater Club and Cheer Leading Varsity is evidently weak. The strategic directions manifested on the vision, mission, goals and strategies of the school with regards to Cultural Affairs Development has been crafted well to cater what the university is expected to become in the future. Analyzation and evaluation of complaints and comments on the improvement of the quality operation management of the Cultural Affairs Development Office with regards to the identification of the quality problems on the strategy implementation is not observed. Support from the administration and involvement of the officials to Cultural Affairs Development Office services are a serious problem met by the faculty and support staff in the delivery of quality cultural services. Lastly, lack of funds is another hardship in the office and also inadequate manpower to help in the quality operation services of the office.

\section{RECOMMENDATIONS}

Based on the conclusions generated, the following recommendations are hereby proposed:The faculty and supports staff must be sent to relevant seminars and workshops to upgrade their knowledge and skills to keep abreast with the trends in cultural development.The Cultural Affairs Development Office must formulate and establish a calendar of activities that is inline with the institution's program of activities. The said calendar of activities must include the practices and rehearsals to have a quality performance. The study recommends that in the improvement of the Cultural Affairs Development Office, criticisms, complaints and comments must be given a chance to be analyzed and be evaluated. It is a perfect benchmark for the planning and formulation of the quality services. Open communication to various stakeholders and clienteles must also be considered. Further, an evaluation on the performances of the office must be done every after the end of every semester.The school administration must extend support to Cultural Affairs Development Office particularly on capabilitybuilding so as to further develop and even sustain the smooth operation of the Office. Furthermore, with regards to lack of funds, the office may strongly provide a valid proposal to be presented to the administration so that the latter will allocate proper amount of fund to be used in the quality services of the office. Lastly, the office may request to the administration an additional faculty or staff to be a part of the team with a proper justification, and results of this study may also serve as a reference material to the administration that will help 
them understand the necessary improvements needed in the strategic quality management of operations of the office to enhance the quality and effectiveness of the organization, their respective faculty, to students, and to the community.

\section{REFERENCES}

[1] Drucker, Peter. "Management Challenges for the $21^{\text {st }}$ Century" Reed Educational and Publishing and Ltd. UK, 2001

[2] Ducker, Peter. "Management In A Time of Great Change" Butterworth- Heinemenn Ltd., Truman Tally Books,USA, 2005

[3] Fahey, Liam and Randall. Robert M. "Learning from the Future, Competitive Foresight Scenarios" John Willey and Sons, Inc. USA 1999

[4] George, Jennifer M. and Jones Gareth R. "Understanding and Managing Organizational Behavior" Addison Wesley Publishing Company, 2000, USA

[5] Kapur, Vipen. "Power Through People and Principles" McGraw-Hill Companies. Malaysia 2000

[6] Myers, Charles B. and Myers Lynn K. "The Professional Educator" Wadsworth Publishing Company, USA. 1995

[7] Petrick, Joseph A. and Furr, Diana S. "Total Quality in Managing Human Resources" St. Lucie Press, Florida, USA 1995

[8] Ersan, Silvino M. "Quality Management Systems of the Furniture Industry ofManadue City: Feasible Proposals" Unpublished Master's Thesis, University of San Carlos, Cebu City, 1993

[9] Holt, John. "An Investigation of the Relationship between Organizational Value Systems and Human Resource Management Systems" Unpublished doctorate Dissertation, University of South Wales(Australia) 2001

[10] Miller, William Johnson. "Development and Testing of a Quality Management Impact Model" Unpublished doctorate dissertation, Georgia State University, 2001

[11] Nicole, Dave. "A New Profession for the Nest Millennium" 2000

[12] Srikanthan G. and Prof. John Dalrymple " Developing a Holistic Model for Quality in Higher Education" 2002

[13] Worsak, Kanok. “ Towards Total Quality Management in Higher Education: The Experience of Asian Institute of Technology” 2002. 